Louisiana State University

LSU Digital Commons

Faculty Publications

Department of Chemistry

7-20-2009

\title{
Demetalation of silver(III) corrolates
}

\author{
Manuela Stefanelli \\ Università degli Studi di Roma Tor Vergata \\ Jing Shen \\ University of Houston \\ Weihua Zhu \\ University of Houston \\ Marco Mastroianni \\ Università degli Studi di Roma Tor Vergata \\ Federica Mandoj \\ Università degli Studi di Roma Tor Vergata
}

See next page for additional authors

Follow this and additional works at: https://digitalcommons.Isu.edu/chemistry_pubs

\section{Recommended Citation}

Stefanelli, M., Shen, J., Zhu, W., Mastroianni, M., Mandoj, F., Nardis, S., Ou, Z., Kadiah, K., Fronczek, F., Smith, K., \& Paolesse, R. (2009). Demetalation of silver(III) corrolates. Inorganic Chemistry, 48 (14), 6879-6887. https://doi.org/10.1021/ic900859a

This Article is brought to you for free and open access by the Department of Chemistry at LSU Digital Commons. It has been accepted for inclusion in Faculty Publications by an authorized administrator of LSU Digital Commons. For more information, please contact ir@lsu.edu. 


\section{Authors}

Manuela Stefanelli, Jing Shen, Weihua Zhu, Marco Mastroianni, Federica Mandoj, Sara Nardis, Zhongping Ou, Karl M. Kadiah, Frank R. Fronczek, Kevin M. Smith, and Roberto Paolesse 


\title{
Demetalation of Silver(III) Corrolates
}

\author{
Manuela Stefanelli ${ }^{\dagger}$, Jing Shen ${ }^{\ddagger}$, Weihua Zhu ${ }^{\ddagger}$, Marco Mastroianni ${ }^{\dagger}$, Federica Mandoj ${ }^{\dagger}$, Sara \\ Nardis $^{\dagger}$, Zhongping Ou ${ }^{\ddagger}$, Karl M. Kadish ${ }^{\ddagger},{ }^{\star}$, Frank R. Fronczek ${ }^{\S}$, Kevin M. Smith ${ }^{\star}, \S$, and \\ Roberto Paolesse ${ }^{*}, \dagger$ \\ tDipartimento di Scienze e Tecnologie Chimiche, Università di Roma Tor Vergata, via della \\ Ricerca Scientifica, 1, 00133 Rome, Italy \\ ‡Department of Chemistry, University of Houston, Houston, Texas 77204-5003 \\ §Department of Chemistry, Louisiana State University, Baton Rouge, Louisiana 70803
}

\begin{abstract}
Several procedures for the demetalation of silver(III) corrolates have been tested. Acidic conditions induce removal of the silver ion but they can also promote concomitant oxidation of the corrole nucleus to an isocorrole species, the degree of which will depend upon the specific acidic media. This oxidation cannot be completely avoided by addition of hydrazine, particularly in the case of 3- $\mathrm{NO}_{2}$ substituted complexes which are quantitatively converted into the corresponding 3$\mathrm{NO}_{2}, 5$-hydroxy isocorroles upon silver ion removal. Several $\beta$-nitro isocorrole products were isolated, and one was structurally characterized. Electrochemical and chemical reductive methods for silver(III) corrolates demetalation were then tested with the aim to avoid the formation of isocorroles. While reaction with sodium borohydride was shown to be quite effective to demetalate unsubstituted silver corrolates this was not the case for the $\beta$-nitro derivatives where the peripheral nitro group is reduced by borohydride giving the corresponding 3 -amino free base corrole species. For the $\beta$-nitro corrole silver complexes, a successful approach was obtained using DBU/THF solutions which afforded the $3-\mathrm{NO}_{2}$ corrole free-base compound as a single reaction product in good yield. These conditions were also effective for unsubstituted corroles although longer reaction times were necessary in this case. To study in greater detail the corrole demetalation behavior, selected $\mathrm{Ag}(\mathrm{III})$ derivatives were characterized by cyclic voltammetry in pyridine, and the demetalation products spectrally characterized after controlled potential reduction in a thin-layer spectroelectrochemical cell.
\end{abstract}

\section{Introduction}

Porphyrin chemistry represents an active field of research which has implications in several disciplines, resulting in many versatile applications such as in photodynamic therapy ${ }^{1}$ or catalysis. ${ }^{2}$ In recent years increasing attention has been devoted to the synthesis and characterization of porphyrin analogues, compounds deriving from skeletal modifications of the porphyrin macrocycle. The most intensely studied of these compounds are the corroles which are core-contracted porphyrins having a corrinoid carbon skeleton, one of the mesocarbon bridges being replaced by a direct pyrrole-pyrrole link. ${ }^{3}$

\footnotetext{
(C) 2009 American Chemical Society

*To whom correspondence should be addressed. kkadish@uh.edu (K.M.K.), kmsmith@1su.edu (K.M.S.), roberto.paolesse@uniroma2.it (R.P.).

Supporting Information Available: CIF file of $\left[\left(3-\mathrm{NO}_{2}\right)(5-\mathrm{OH}) \mathrm{TT}\right.$ isoCor $] \mathrm{H}_{2}$ and $\mathrm{UV}-\mathrm{vis}$ spectrum of $\left(\mathrm{NO}_{2} \mathrm{~T} t B u \mathrm{PCo}\right) \mathrm{H}_{3}$. This material is available free of charge via the Internet at http://pubs.acs.org.
} 
Corroles possess excellent chelating properties and numerous metal derivatives have been synthesized and examined as to their structure-property relationships for both theoretical and practical reasons. ${ }^{4}$ In many cases, the metallocorroles exhibit a coordination chemistry which is different than that of the analogous porphyrins because of the reduced inner cavity size and the trianionic ligand character of the corrole macrocycle, thus resulting in a stabilization of derivatives having higher formal oxidation states of the central metal ions than in the case of the porphyrins. ${ }^{5}$

Early research on corroles was hampered by the need for time-consuming and laborious preparation, but new synthetic routes for obtaining 5,10,15-triarylcorroles ${ }^{3}$ have enabled a variety of detailed studies to be carried out on these macrocycles, leading to a large number of publications on various aspects of these compounds. The increased availability of corroles in large quantities has also led to these compounds being examined for possible use in several practical applications. ${ }^{6}$ From this point of view it is important to develop protocols for peripheral functionalization of the corrole macrocycle with an aim toward tuning and optimizing the properties of the corrole for a particular application.

Our laboratories have been involved in functionalization of corroles for quite some time, ${ }^{7}$ with recent publications being devoted to peripheral bromination, hydroformylation, and, more recently, nitration of the macrocycle. ${ }^{8}$ The free-base corrole frequently exhibits a very specific reactivity, giving unexpected reaction products. While this behavior is intriguing and challenging in itself, it is not useful for the preparation of rationally functionalized macrocycles.

To functionalize related porphyrins, the macrocycle is protected and/or activated toward a particular reaction by coordination with a given metal ion. In this context, a reversibility of the metalation and demetalation reactions involving the macrocycle and the central metal ion is needed to obtain a functionalized free-base macrocycle at the end of the reaction. This approach has been hindered for corroles by a lack of demetalation protocols, and this is due in large part to the inherent instability of the corrole macrocycle in acid media where structurally modified corroles and/or decomposition products are readily formed. Nonetheless, this situation has changed in recent years, and several efficient methods have been reported for removal of metallocorrole central metal ions under controlled conditions. ${ }^{9}$ Among the examined compounds are the silver(III) corroles which were the first examples reported in the literature for a reversible metalation/demetalation process. ${ }^{9 b}$ Demetalation in the initial report was accomplished by treatment of the silver corrole with concentrated $\mathrm{HCl}$, but a detailed procedure was not reported.

In our laboratory we have recently developed a regioselective $\beta$-nitration method for preparing meso-triarylcorroles using silver nitrite as a nitrating system. ${ }^{7}$ This simple procedure affords in moderate yields a 3-nitrosubstituted $\mathrm{Ag}(\mathrm{III})$ corrolate as the reaction product. This compound is particularly appealing because of the well-known potentialities of the nitro group for efficient incorporation of functionality into the $\beta$-pyrrole positions of the macrocycle, thus allowing for further manipulation of the corrole platform. ${ }^{10}$ For this reason, the availability of a simple procedure for $\mathrm{Ag}(\mathrm{III})$ corrolate demetalation is of fundamental interest to further exploit this synthetic route, as well as for the preparation of more elaborate corrole derivatives.

The need for well-defined methods for removal of metal ions from the corrole macrocycle led us to examine in detail new routes for demetalation. The results of our studies are described in the present paper which examines seven triaryl silver(III) corroles, three of which are nitrated at the conjugated macrocycle. The investigated compounds are shown in Chart 1 . Because a reduction mechanism is presumably involved in the demetalation 
process, in analogy with silver porphyrins, ${ }^{11}$ we have performed electrochemical studies on both the silver triarycorrolates and the corresponding nitro derivatives to elucidate the redox processes involved and have spectrally characterized the corrole demetalation product after controlled potential reduction in a thin-layer cell.

\section{Experimental Section}

\section{Chemicals}

Pyridine (py) was obtained from Sigma-Aldrich Co. and used as received for electrochemistry and spectroelectrochemistry experiments. Tetra- $n$-butylammonium perchlorate (TBAP) was purchased from Fluka Chemical Co. and used without further purification. Silica gel 60 (70-230 mesh, Merck) was used for column chromatography. Reagents and solvents (Aldrich, Merck, or Fluka) were of the highest grade available and were used without further purification.

\section{Instrumentation}

Reactions were monitored by thin layer chromatography and UV-vis spectrophotometry. ${ }^{1} \mathrm{H}$ NMR spectra were recorded with a Bruker Avance $300(300 \mathrm{MHz})$ instrument, using $\mathrm{CDCl}_{3}$ as solvent: chemical shifts are expressed in ppm relative to residual $\mathrm{CHCl}_{3}(7.25 \mathrm{ppm})$. UVvis spectra were measured with a Varian Cary 50 Spectrophotometer. Mass spectra were obtained using a VG quattro Spectrometer (FAB). Synthesis of 5,10,15-triarylcorroles and the corresponding silver complexes were prepared as previously reported in literature, ${ }^{8 \mathrm{a}, 12}$ while the preparation of $\left(\mathrm{TF}_{5} \mathrm{PCor}\right) \mathrm{Ag}$ is reported for the first time in the present work.

Cyclic voltammetry was carried out at $298 \mathrm{~K}$ by using an EG\&G Princeton Applied Research (PAR) 173 potentiostat/galvanostat. A homemade three-electrode cell was used for cyclic voltammetric measurements and consisted of a glassy carbon working electrode, a platinum counter electrode, and a homemade saturated calomel reference electrode (SCE). The SCE was separated from the bulk of the solution by a fritted glass bridge of low porosity which contained the solvent/supporting electrolyte mixture.

Thin-layer UV-visible spectroelectrochemical experiments were performed with a homebuilt thin-layer cell which has a light transparent platinum net working electrode. ${ }^{13}$ Potentials were applied and monitored with an EG\&G PAR Model 173 potentiostat. Timeresolved UV-visible spectra were recorded with a Hewlett-Packard Model 8453 diode array spectrophotometer. High purity $\mathrm{N}_{2}$ from Trigas was used to deoxygenate the solution and kept over the solution during each electrochemical and spectroelectrochemical experiment.

The crystal structure of $\left[\left(3-\mathrm{NO}_{2}\right)(5-\mathrm{OH}) \mathrm{TT}\right.$ isoCor] $\mathrm{H}_{2}$ was determined at low temperature using data collected with $\mathrm{Cu} \mathrm{Ka}$ radiation on a Bruker Kappa Apex II diffractometer.

Crystal data: $\mathrm{C}_{40} \mathrm{H}_{31} \mathrm{~N}_{5} \mathrm{O}_{3}$, dark green, triclinic space group $P \overline{1}, a=7.7596(5), b=11.0531(7)$, $c=18.6697(10) \AA, a=96.019(5), \beta=98.975(5), \gamma=96.284(5)^{\circ}, V=1559.98(16) \AA^{3}, Z=2$, $D_{\text {calc }}=1.341 \mathrm{~g} \mathrm{~cm}^{-3}, \mu(\mathrm{Cu} \mathrm{Ka})=0.69 \mathrm{~mm}^{-1}, T=90 \mathrm{~K}, 11984$ reflections having $\theta_{\max }=58.9^{\circ}$ measured, 4281 independent reflections $\left(R_{\mathrm{int}}=0.037\right)$ were used in the calculations. All $\mathrm{H}$ atoms were located by difference maps. Those on $\mathrm{C}$ were placed in idealized positions, while coordinates for those on $\mathrm{N}$ and $\mathrm{O}$ were refined. Final residuals (for 446 parameters) were $R_{1}[I>2 \sigma(I)]=0.039, \mathrm{w} R_{2}$ (all data) $=0.104, \mathrm{CCDC} 722641$.

\section{General Procedures for Demetalation}

(a). $\mathrm{CHCl}_{3} / \mathrm{H}_{2} \mathrm{SO}_{4}$ Method-Concentrated $\mathrm{H}_{2} \mathrm{SO}_{4}(1 \mathrm{~mL})$ was added to a chloroform solution $(10 \mathrm{~mL})$ of (TtBuTPCor) $\mathrm{Ag}(0.2 \mathrm{mmol})$. The progress of the demetalation reaction 
was monitored by UV-vis spectroscopy, by diluting an aliquot of the reaction mixture in $\mathrm{CH}_{3} \mathrm{OH}$. The immediate formation of the corrole cation was observed and, after $5 \mathrm{~min}$, distilled water $(50 \mathrm{~mL})$ was added, and the organic phase extracted by adding chloroform $(50 \mathrm{~mL})$. The organic mixture was washed twice with distilled water, then neutralized twice with aqueous $\mathrm{NaHCO}_{3}$ and dried over $\mathrm{Na}_{2} \mathrm{SO}_{4}$. Purification on silica gel (eluant: dichloromethane/hexane $1: 1$ ) and crystallization from $\mathrm{CH}_{2} \mathrm{Cl}_{2} /$ hexane afforded the demetalated corrole (TtBuTPCor) $\mathrm{H}_{3}$ ( $0.019 \mathrm{mmol}, 18 \%$ yield), identical to an authentic specimen prepared according to literature methods. ${ }^{8 \mathrm{a}}$

(b). $\mathrm{NaBH}_{4}$ Method-(TtBuTPCor)Ag (28 mg, $0.035 \mathrm{mmol}$ ) was dissolved in $30 \mathrm{~mL}$ of a $\mathrm{CH}_{2} \mathrm{Cl}_{2} / \mathrm{CH}_{3} \mathrm{OH}$ (4:1) solvent mixture, and the solution degassed with Ar for 5 min. $\mathrm{NaBH}_{4}$ (66 mg, $1.75 \mathrm{mmol}$ ) was added, and the reaction was monitored by thin-layer chromatography (TLC, silica gel, dichloromethane elution) and UV-vis spectroscopy. The demetalation was complete after $1 \mathrm{~h}$. After this time, the solution was filtered through a Celite plug, the solvent removed under vacuum, and the residue was purified by column chromatography on silica gel (eluant: $\mathrm{CH}_{2} \mathrm{Cl}_{2}$ /hexane 4:1). The first green fraction was isolated and crystallized from $\mathrm{CH}_{2} \mathrm{Cl}_{2} / \mathrm{CH}_{3} \mathrm{OH}$, affording $13 \mathrm{mg}(0.019 \mathrm{mmol}, 54 \%$ yield $)$ of the corrole free base (TtBuTPCor) $\mathrm{H}_{3}$.

(c). NaOH/EtOH-Toluene Method-(TtBuTPCor)Ag (0.03 mmol) was dissolved in a mixture of EtOH/toluene $(0.5 \mathrm{~mL} / 10 \mathrm{~mL})$ containing $1.5 \mathrm{mmol}$ of $\mathrm{NaOH}$, and the solution was refluxed for about $1.5 \mathrm{~h}$. The progress of the demetalation reaction was monitored by $\mathrm{UV}$-vis spectroscopy and TLC (silica gel, $\mathrm{CH}_{2} \mathrm{Cl}_{2}$-petroleum ether (3:1)). After the starting complex was fully consumed, the solvent was removed under vacuum, and the residue dissolved inCH $\mathrm{CH}_{2} \mathrm{Cl}_{2}$. The organic phase was washed twice with distilled water and then dried over $\mathrm{Na}_{2} \mathrm{SO}_{4}$. Chromatography on silica gel (eluant: $\mathrm{CH}_{2} \mathrm{Cl}_{2} /$ hexane $3: 1$ ), followed by crystallization from $\mathrm{CH}_{2} \mathrm{Cl}_{2}-\mathrm{CH}_{3} \mathrm{OH}$ afforded the corresponding corrole free base (yield $38 \%)$.

(d). DBU/THF Method-To a stirred solution of silver corrole complex $(0.053 \mathrm{mmol})$ dissolved in tetrahydrofuran (THF, $10 \mathrm{~mL}$ ) $154 \mu \mathrm{L}$ of DBU (1.05 mmol) were added. The progress of the reaction was monitored by UV-vis spectroscopy and TLC (silica gel, eluant: $\mathrm{CH}_{2} \mathrm{Cl}_{2}$ /hexane $3: 1$ ). When the silver complex was fully consumed, the solvent was removed under vacuum, the residue dissolved in $\mathrm{CH}_{2} \mathrm{Cl}_{2}$, and the organic mixture washed twice with distilled water $(50 \mathrm{~mL})$. The organic solution was dried over $\mathrm{Na}_{2} \mathrm{SO}_{4}$ and then purified on silica gel (eluant: $\mathrm{CH}_{2} \mathrm{Cl}_{2} /$ hexane 1:1). All fractions containing the corrole free base were then collected, and the solvent was evaporated. The residue was dissolved in $\mathrm{CHCl}_{3}(10 \mathrm{~mL})$, and an aliquot of an aqueous solution of hydrazine $(1 \mathrm{~mL})$ was added. The organic mixture was washed twice with distilled water, dried over $\mathrm{Na}_{2} \mathrm{SO}_{4}$, and then crystallized from $\mathrm{CH}_{2} \mathrm{Cl}_{2}-\mathrm{CH}_{3} \mathrm{OH}$, affording the demetalated corrole [(TtBuTPCor $) \mathrm{H}_{3}$ : $62 \%$ yield, $\left(\mathrm{NO}_{2} \mathrm{~T} t B u\right.$ PCor $) \mathrm{H}_{3}: 45 \%$ yield].

\section{Preparation of $\left(\mathrm{TF}_{5} \mathrm{PCor}\right) \mathrm{Ag}$}

$\left(\mathrm{TF}_{5} \mathrm{PCor}\right) \mathrm{H}_{3}(80 \mathrm{mg}, 0.1 \mathrm{mmol})$ was dissolved in acetonitrile $(10 \mathrm{~mL})$, and silver(I) acetate (55 mg, $0.33 \mathrm{mmol}$ ) was added. Stirring of the solution was continued at room temperature (RT), and the progress of the reaction was monitored by TLC and UV-vis spectroscopy. After $18 \mathrm{~h}$, the reaction mixture was filtered through a Celite plug, the solvent removed under vacuum, and the residue purified by column chromatography on silica gel. Hexane was initially used as eluant, and increasing amounts of chloroform (up to 20\%) afforded the desired product as the first fraction and the unreacted free-base-corrole as the second. The first red-violet fraction was isolated and crystallized from acetone/ $\mathrm{H}_{2} \mathrm{O}$, affording $32 \mathrm{mg}$ $(0.036 \mathrm{mmol}, 36 \%)$ of $\left(\mathrm{TF}_{5} \mathrm{PCor}\right) \mathrm{Ag}$ as purple crystals. UV-vis: $\lambda_{\max }\left(\mathrm{CH}_{2} \mathrm{Cl}_{2}, \log \varepsilon\right): 421$ 
(5.01), 493 (3.76), 530 (3.87), 564 (4.32) nm. ${ }^{1} \mathrm{H}$ NMR (300 MHz, $\mathrm{CDCl}_{3}$ ): $\delta 9.38$

(d, ${ }^{1} J=4.2 \mathrm{~Hz}, 2 \mathrm{H}, \beta$-pyrrolic), $9.00\left(\mathrm{~d},{ }^{1} J=4.2 \mathrm{~Hz}, 2 \mathrm{H}, \beta\right.$-pyrrolic), $8.82\left(\mathrm{~d},{ }^{1} J=4.0 \mathrm{~Hz}, 4 \mathrm{H}\right.$, $\beta$-pyrrolic)

\section{Spectroscopic Characterization of Compounds}

[(3- $\left.\left.\mathrm{NO}_{2}\right)-(5-\mathrm{OH}) \mathbf{t B u T P i s o C o r}\right] \mathrm{H}_{2}$-Anal. found for $\mathrm{C}_{49} \mathrm{H}_{49} \mathrm{~N}_{5} \mathrm{O}_{3}: \mathrm{C}, 77.8: \mathrm{H}, 6.6$; N, 9.4. Calcd: $\mathrm{C}, 77.9 ; \mathrm{H}, 6.7 ; \mathrm{N}, 9.3 \%$. UV-vis: $\lambda_{\max }\left(\mathrm{CH}_{2} \mathrm{Cl}_{2}, \log \varepsilon\right)=398$ (4.79), 622 (4.09), $674(4.08) \mathrm{nm} .{ }^{1} \mathrm{H}$ NMR (300 MHz, $\left.\mathrm{CDCl}_{3}\right): \delta=16.37$ (s, 1H, NH), 14.97 (s, $\left.1 \mathrm{H}, \mathrm{NH}\right), 7.53$ (s, br, 5H, phenyl), 7.50 (s, br, $1 \mathrm{H}$, phenyl), $7.40(\mathrm{~m}, 5 \mathrm{H}$, phenyl $+\beta$-pyrrolic), 7.15 (d, ${ }^{1} J=3.63 \mathrm{~Hz}, 2 \mathrm{H}$, phenyl), 6.92 (m, $2 \mathrm{H}, \beta$-pyrrolic), 6.73 (d, ${ }^{1} J=4.71 \mathrm{~Hz}, 1 \mathrm{H}, \beta$-pyrrolic), $6.55(\mathrm{~m}, 1 \mathrm{H}, \beta$-pyrrolic), 6.36 (s, $1 \mathrm{H}, \beta$-pyrrolic), $6.30(\mathrm{~m}, 1 \mathrm{H}, \beta$-pyrrolic), $1.42(\mathrm{~s}, 9 \mathrm{H},-$ $\left.\mathrm{C}\left(\mathrm{CH}_{3}\right)_{3}\right), 1.39$ (s, 9H, -C( $\left.\left.\mathrm{CH}_{3}\right)_{3}\right), 1.27 \mathrm{ppm}\left(\mathrm{s}, 9 \mathrm{H},-\mathrm{C}\left(\mathrm{CH}_{3}\right)_{3}\right)$. LRMS (FAB): $\mathrm{m} / \mathrm{z} 755$ $\left(\mathrm{M}^{+}\right)$.

[(3- $\left.\mathrm{NO}_{2}\right)(5-\mathrm{OH})$ TTisoCor] $\mathrm{H}_{2}$-Anal. found for $\mathrm{C}_{40} \mathrm{H}_{31} \mathrm{~N}_{5} \mathrm{O}_{3}$ : C, 76.4: $\mathrm{H}, 4.9 ; \mathrm{N}, 11.2$. Calcd: C, 76.3; $\mathrm{H}, 5.0 ; \mathrm{N}, 11.1 \%$. UV-vis: $\lambda_{\max }\left(\mathrm{CH}_{2} \mathrm{Cl}_{2}, \log \varepsilon\right)=397$ (4.75), 616 (4.06), $672(4.01) \mathrm{nm} .{ }^{1} \mathrm{H}$ NMR $\left(300 \mathrm{MHz}, \mathrm{CDCl}_{3}\right): \delta=16.35$ (s, $\left.1 \mathrm{H}, \mathrm{NH}\right), 14.95(\mathrm{~s}, 1 \mathrm{H}, \mathrm{NH}), 7.53$ (s, br, 4H, phenyl), 7.50 (s, br, $1 \mathrm{H}$, phenyl), $7.40(\mathrm{~m}, 5 \mathrm{H}$, phenyl $+\beta$-pyrrolic), 7.15 (d, ${ }^{1} J=3.63 \mathrm{~Hz}, 2 \mathrm{H}$, phenyl), 6.92 (m, 2H, $\beta$-pyrrolic), 6.73 (d, ${ }^{1} J=4.71 \mathrm{~Hz}, 1 \mathrm{H}, \beta$-pyrrolic), $6.55(\mathrm{~m}, 1 \mathrm{H}, \beta$-pyrrolic), 6.36 (s, $1 \mathrm{H}, \beta$-pyrrolic), $6.30(\mathrm{~m}, 1 \mathrm{H}, \beta$-pyrrolic), $1.42(\mathrm{~s}, 9 \mathrm{H}$, $\left.\mathrm{C}\left(\mathrm{CH}_{3}\right)_{3}\right), 1.39$ (s, 9H, $\left.-\mathrm{C}\left(\mathrm{CH}_{3}\right)_{3}\right), 1.27 \mathrm{ppm}\left(\mathrm{s}, 9 \mathrm{H},-\mathrm{C}\left(\mathrm{CH}_{3}\right)_{3}\right)$. LRMS (FAB): $\mathrm{m} / z 628$ $\left(\mathrm{M}^{+}\right)$.

[(10-OH)tBuTPisoCor] $\mathrm{H}_{2}$-Anal. found for $\mathrm{C}_{49} \mathrm{H}_{50} \mathrm{~N}_{4} \mathrm{O}: \mathrm{C}, 82.9: \mathrm{H}, 6.9 ; \mathrm{N}$, 7.7. Calcd: C, 82.8; H, 7.1; N, 7.8\%. UV-vis: $\lambda_{\max }\left(\mathrm{CH}_{2} \mathrm{Cl}_{2}, \log \varepsilon\right)=360$ (4.47), 433 (4.68), 670 (3.83), 725 (3.86) nm. ${ }^{1} \mathrm{H}$ NMR (300 MHz, $\left.\mathrm{CDCl}_{3}\right): \delta=15.62$ (s, 2H, NH), 7.59 (d, ${ }^{1} J=8.4 \mathrm{~Hz}, 2 \mathrm{H}$, phenyl), $7.48\left(\mathrm{~d},{ }^{1} J=8.1 \mathrm{~Hz}, 4 \mathrm{H}\right.$, phenyl), $7.26\left(\mathrm{~d},{ }^{1} J=8.1 \mathrm{~Hz}, 4 \mathrm{H}\right.$, phenyl), $7.06\left(\mathrm{~d},{ }^{1} J=7.8\right.$ $\mathrm{Hz}, 2 \mathrm{H}$, phenyl), 6.69 (m, 4H, $\beta$-pyrrolic), 6.64 (d, ${ }^{1} J=4.5 \mathrm{~Hz}, 2 \mathrm{H}, \beta$-pyrrolic), 6.40 (d, ${ }^{1} \mathrm{~J}=4.2 \mathrm{~Hz}, 2 \mathrm{H}, \beta$-pyrrolic), $1.61 \mathrm{ppm}\left(\mathrm{s}, 27 \mathrm{H},-\mathrm{C}\left(\mathrm{CH}_{3}\right)_{3}\right)$. LRMS (FAB): $\mathrm{m} / z 710\left(\mathrm{M}^{+}\right)$.

[(5-OH)tBuTPisoCor] $\mathrm{H}_{2}$-Anal. found for $\mathrm{C}_{49} \mathrm{H}_{50} \mathrm{~N}_{4} \mathrm{O}: \mathrm{C}, 82.6: \mathrm{H}, 7.0 ; \mathrm{N}$, 7.8. Calcd: C, 82.4; H, 7.1; N, 7.7\%. UV-vis: $\lambda_{\max }\left(\mathrm{CH}_{2} \mathrm{Cl}_{2}, \log \varepsilon\right)=407$ (4.69), 680 (3.86), 738 (3.83) nm. ${ }^{1} \mathrm{H}$ NMR (300 MHz, $\left.\mathrm{CDCl}_{3}\right): \delta=16.21(\mathrm{~s}, 1 \mathrm{H}, \mathrm{NH}), 15.84(\mathrm{~s}, 1 \mathrm{H}, \mathrm{NH}), 7.59\left(\mathrm{~d},{ }^{1} J=8.1\right.$ $\mathrm{Hz}, 2 \mathrm{H}$, phenyl), $7.42\left(\mathrm{~d},{ }^{1} J=7.8 \mathrm{~Hz}, 2 \mathrm{H}\right.$, phenyl), $7.27\left(\mathrm{~m}, 6 \mathrm{H}\right.$, phenyl), $7.07\left(\mathrm{~d},{ }^{1} \mathrm{~J}=8.1 \mathrm{~Hz}\right.$, $2 \mathrm{H}$, phenyl), 6.95 (d, ${ }^{1} J=4.5 \mathrm{~Hz}, 1 \mathrm{H}, \beta$-pyrrolic), 6.84 (d, ${ }^{1} J=4.5 \mathrm{~Hz}, 1 \mathrm{H}, \beta$-pyrrolic), 6.56 (m, $2 \mathrm{H}, \beta$-pyrrolic), 6.51 (d, ${ }^{1} J=4.5 \mathrm{~Hz}, 1 \mathrm{H}, \beta$-pyrrolic), 6.30 (m, $1 \mathrm{H}, \beta$-pyrrolic), $6.14(\mathrm{~m}$, $1 \mathrm{H}, \beta$-pyrrolic), $6.02\left(\mathrm{~m}, 1 \mathrm{H}, \beta\right.$-pyrrolic), 1.61 (s, $\left.18 \mathrm{H},-\mathrm{C}\left(\mathrm{CH}_{3}\right)_{3}\right), 1.59\left(\mathrm{~s}, 9 \mathrm{H},-\mathrm{C}\left(\mathrm{CH}_{3}\right)_{3}\right)$. LRMS (FAB): $m / z 710\left(\mathrm{M}^{+}\right)$.

( $\mathrm{NO}_{2}$ TtBuPCor) $\mathrm{H}_{3}$-Anal. found for $\mathrm{C}_{49} \mathrm{H}_{49} \mathrm{~N}_{5} \mathrm{O}_{2}:$ C, 79.3: H, 6.9; N, 9.4. Calcd: C, 79.5; H, 6.7; N, 9.5\%. UV-vis: $\lambda_{\max }\left(\mathrm{CH}_{2} \mathrm{Cl}_{2}, \log \varepsilon\right)=397$ (4.64), 438 (4.68), 465 (4.69), 664 (4.29) nm. ${ }^{1} \mathrm{HNMR}\left(300 \mathrm{MHz}, \mathrm{CDCl}_{3}\right): \delta=9.07$ (s, $1 \mathrm{H}, \beta$-pyrrolic), 8.66 (s, br, $3 \mathrm{H}$, phenyl), 8.52 (s, $1 \mathrm{H}, \beta$-pyrrolic), 8.37 (s, $1 \mathrm{H}, \beta$-pyrrolic), 8.28 (s, $1 \mathrm{H}, \beta$-pyrrolic), $8.20(\mathrm{~s}, \mathrm{br}, 2 \mathrm{H}$, phenyl), $8.04\left(\mathrm{~m}, 4 \mathrm{H}\right.$, phenyl), $7.80\left(\mathrm{~m}, 6 \mathrm{H}\right.$, phenyl), $1.60 \mathrm{ppm}\left(\mathrm{s}, 27 \mathrm{H},-\mathrm{C}\left(\mathrm{CH}_{3}\right)_{3}\right)$. LRMS (FAB): $\mathrm{m} / z 740\left(\mathrm{M}^{+}\right)$.

( $\left.\mathrm{NH}_{\mathbf{2}} \mathbf{T T C o r}\right) \mathrm{H}_{3}$-Anal. found for $\mathrm{C}_{40} \mathrm{H}_{33} \mathrm{~N}_{5}: \mathrm{C}, 85.0: \mathrm{H}, 4.8 ; \mathrm{N}, 10.2$. Calcd: C, 85.1; $\mathrm{H}$, 4.8; N, 10.1\%. UV-vis: $\lambda_{\max }\left(\mathrm{CH}_{2} \mathrm{Cl}_{2}, \log \varepsilon\right)=418(4.71), 578(4.06), 635(3.88) \mathrm{nm} .{ }^{1} \mathrm{H}$ NMR (300 MHz, $\left.\mathrm{CDCl}_{3}\right): \delta=8.86\left(\mathrm{~d},{ }^{1} J=4.7 \mathrm{~Hz}, 1 \mathrm{H}, \beta\right.$-pyrrolic), $8.81\left(\mathrm{~d},{ }^{1} J=3.8 \mathrm{~Hz}, 1 \mathrm{H}\right.$, $\beta$-pyrrolic), 8.55 (d, ${ }^{1} J=4.7 \mathrm{~Hz}, 1 \mathrm{H}, \beta$-pyrrolic), 8.51 (d, ${ }^{1} J=4.3 \mathrm{~Hz}, 1 \mathrm{H}, \beta$-pyrrolic), 8.45 (m, $2 \mathrm{H}, \beta$-pyrrolic), $8.29\left(\mathrm{~d},{ }^{1} J=7.6 \mathrm{~Hz}, 2 \mathrm{H}\right.$, phenyl), $8.06\left(\mathrm{~d},{ }^{1} J=7.4 \mathrm{~Hz}, 4 \mathrm{H}\right.$, phenyl), 7.98 
(s, 1H, $\beta$-pyrrolic), 7.63 (m, 4H, phenyl), 7.55 (d, ${ }^{1} J=7.4 \mathrm{~Hz}, 2 \mathrm{H}$, phenyl), $2.69 \mathrm{ppm}(\mathrm{s}, 9 \mathrm{H},-$ $\mathrm{CH}_{3}$ ). LRMS (FAB): $\mathrm{m} / z 691\left(\mathrm{M}^{+}\right)$.

\section{Results and Discussion}

Studies of demetalation were carried out with (TtBuPCor) Ag and the corresponding 3$\left(\mathrm{NO}_{2}\right)$ derivative. We started with the most general routes previously used in the case of porphyrins. These involve the removal of the central metal ion in aqueous solutions containing different acids, examples being $\mathrm{H}_{2} \mathrm{SO}_{4}$, halogenated acids, or organic acids like TFA, the exact choice depending upon the stability by the complex. However, the exploitation of such harsh acid protocols to metallocorroles has been problematic because of the increased reactivity of the corrole macrocycle in acid media, which can easily lead to peripheral substitution and/or decomposition products. ${ }^{14}$

Considering this crucial aspect, we initially used the biphasic method reported by Brückner et al., ${ }^{9 \mathrm{~b}}$ to determine the most accurate experimental protocol. For this purpose, we prepared a solution of (TtBuPCor) Ag in chloroform and added the same volume of $1 \mathrm{M} \mathrm{HCl}$. The progress of the reaction was monitored by UV-vis spectroscopy after acid addition and no changes in the spectral features were observed under these conditions. Increasing the acid concentration to $4 \mathrm{M}$ led to formation of the corrole cation in $1 \mathrm{~h}$, but the reaction workup afforded almost quantitatively the starting complex together with traces of an isocorrole species, ${ }^{7,15}$ as recently reported in the case of copper corrole demetalation using different acidic mixtures. ${ }^{9 \mathrm{~b}}$ Similar results were obtained after adding a few drops of concentrated $\mathrm{HCl}$ to a chloroform mixture containing (TtBuPCor)Ag.

When the same procedure was applied to $\left(\mathrm{NO}_{2} \mathrm{~T} t \mathrm{BuPCor}\right) \mathrm{Ag}$, the UV-vis spectrum revealed a complete transformation of the starting complex into a different compound in about $12 \mathrm{~h}$. TLC analysis showed the almost quantitative formation of a green band having a lower $R_{f}$ value than the starting macrocycle. Subsequent purification of the crude mixture afforded an analytically pure compound that was spectroscopically characterized as an isocorrole. The presence of a blue-shifted Soret band below $400 \mathrm{~nm}$ and two bands above $600 \mathrm{~nm}$ in the visible spectrum combined with NMR data which showed resonances at about $15 \mathrm{ppm}$ for the inner $\mathrm{NH}$ and the $\beta$-pyrrolic resonances shifted below $7 \mathrm{ppm}$, supported formation of $\left[\left(3-\mathrm{NO}_{2}\right)(5-\mathrm{OH}) t B u\right.$ TPisoCor $] \mathrm{H}_{2}$. This is analogous to results from our previous experiments on the demetalation of $\mathrm{Cu}(\mathrm{III})$ corrolates. ${ }^{9 \mathrm{~b}}$ Attempts to obtain crystals suitable for X-ray analysis were unsuccessful, but the same demetalation protocol carried out on $\left(\mathrm{NO}_{2} \mathrm{TT}\right.$-Cor) $\mathrm{Ag}$ afforded a single compound with similar spectroscopic features, for which single crystals were obtained by slow diffusion of methanol into a diluted dichloromethane solution. An X-ray crystal structure determination of this compound unambiguously confirmed it to be $\left[\left(3-\mathrm{NO}_{2}\right)-(5-\mathrm{OH}) \mathrm{TTisoCor}\right] \mathrm{H}_{2}$ (Figure 1). Although the oxidative formation of isocorroles generally gives a statistical mixture of 5- and 10-substituted compounds, ${ }^{15}$ the demetalation of 3- $\mathrm{NO}_{2}$-triarylcorroles affords exclusively the 5-hydroxy substituted isocorrole, whose formation is clearly favored by the intramolecular hydrogen bond established between the hydroxyl and nitro groups on the compound (as evidenced in Figure 1).

The intramolecular $\mathrm{OH} \cdots \mathrm{O}$ hydrogen bond to the nitro group is normal and approximately linear, having $\mathrm{O} \cdots \mathrm{O}$ distance $2.714(2) \AA$ and a $163(2)^{\circ}$ angle about $\mathrm{H}$. The four corrole $\mathrm{N}$ atoms are essentially coplanar, exhibiting a mean deviation of $0.010(1) \AA$. NH hydrogen atoms appear ordered and have a direction preference toward one adjacent $\mathrm{N}$ atom $(\mathrm{N}-\mathrm{H} \cdots \mathrm{N}$ angles $\left.135(2)^{\circ}\right)$ over the other $\left(\mathrm{N}-\mathrm{H} \cdots \mathrm{N}<110^{\circ}\right)$. The 23 -atom corrole core has a flattened saddle conformation, with the nitrated pyrrole forming a dihedral angle of $9.0(3)^{\circ}$ with the pyrrole ring opposite it, while the other two opposite pyrroles are more steeply inclined, 
forming a dihedral angle of $29.7(1)^{\circ}$. Overall, the $23 \mathrm{C}$ and $\mathrm{N}$ atoms have a mean deviation of $0.18 \AA$ from coplanarity, with a maximum of $0.536(2) \AA$ for a $\mathrm{C}$ atomon the periphery a pyrrole ring.

This result led us to turn our attention to other demetalation systems exploiting acidic conditions; we decided to use trifluoroacetic acid (TFA) in $\mathrm{CH}_{2} \mathrm{Cl}_{2}$, a system recently reported for the reductive demetalation of 3-Aryl- and 3-arylethynyl NCP silver(III) complexes. ${ }^{16}$ For this purpose, (TtBuPCor) Ag was dissolved in the $\mathrm{CH}_{2} \mathrm{Cl}_{2} / \mathrm{TFA}$ mixture, and the course of the reaction followed by UV-vis spectroscopy. After 5 min, the UV-vis. spectrum indicated formation of the corrole cation, but subsequent treatment with an aliquot of TEA showed an overlapping of the optical features for both the starting complex and an isocorrole. After $45 \mathrm{~min}$ the complete disappearance of the original silver corrolate was observed, but the UV-vis spectrum indicated exclusive formation of an isocorrole. Neutralization with aqueous $\mathrm{NaHCO}_{3}$ and TLC of the crude reaction product confirmed the absence of the expected free-base corrole among the reaction products. After treatment by column chromatography, the hydroxyisocorrole was recovered. Application of the same demetalation procedure to $\left(\mathrm{NO}_{2} \mathrm{~T} t \mathrm{Bu}\right.$ PCor $) \mathrm{Ag}$ led to an almost immediate conversion to the nitroisocorrole which possesses identical spectroscopic characteristics as that obtained using the biphasic method described above.

The failure of the above-described demetalation protocols, which leave unchanged the starting complex or completely transform it into the corresponding isocorrole, led us to investigate as the acidic mixture $\mathrm{CHCl}_{3} / \mathrm{H}_{2} \mathrm{SO}_{4}$ which was recently used for the efficient removal of copper ions from meso-triaryl-, $\beta$-octaalkyl- and fully substituted corroles. ${ }^{9 \mathrm{~b}}$ This protocol reduced decomposition of the starting complex and remarkably prevented oxidation of the corrole ring, which leads in general to the formation of isocorroles. Considering these favorable aspects, we applied the above procedure to both silver complexes, but the results were not as satisfying as in the case of the copper corrolates.

Applying the demetalation procedure to $\left(\mathrm{NO}_{2} \mathrm{~T} t \mathrm{Bu}\right.$ PCor $) \mathrm{Ag}$ again led to a nitro isocorrole as the main reaction product, while better results were obtained with (TtBuPCor)Ag. Monitoring the progress of the reaction by UV-vis spectroscopy showed the starting complex to be totally consumed in $5 \mathrm{~min}$ with formation of a product ascribed to a $\pi$-radical species of the corrole macrocycle, as recently reported in the literature. ${ }^{17}$ Treatment of this reaction product in the mixture with aqueous $\mathrm{NaHCO}_{3}$ and purification on a column afforded three fractions. The first isolated brown band corresponded to the above-mentioned corrole radical that could be easily converted into its aromatic form by treatment with a few drops of aqueous hydrazine. The second green fraction was identified as the expected $(\mathrm{T} t \mathrm{~B} u \mathrm{PCor}) \mathrm{H}_{3}$ while a more polar third green band corresponded to an isocorrole, which was the main reaction product. Although reduction of the compound in the first band by hydrazine increased the amount of the demetalated corrole, the overall reaction yield was still very low as compared with the analogous reaction performed on copper corrolates.

Using acidic mixtures of different strengths has been demonstrated to be quite ineffective for demetalation of silver corroles, and for this reason we turned our attention to reductive methods used for the removal of silver ion from porphyrins and carbaporphyrins. ${ }^{11}$ Collman et al. reported in 1983 the use of $\mathrm{NaBH}_{4}$ as an efficient demetalation reagent for silver porphyrins, ${ }^{18}$ and its reducing mechanism was elucidated by Cowan and Sanders ${ }^{19}$ a few years later. Following a slightly modified protocol, we demetalated (T $t B u$ PCor)Ag by treatment of the complex with excess $\mathrm{NaBH}_{4}$ in a $\mathrm{CH}_{2} \mathrm{Cl}_{2} / \mathrm{CH}_{3} \mathrm{OH}$ solution at room temperature. In this case, the color of the reaction mixture rapidly turned from claret to brilliant green, and in about $1 \mathrm{~h}$ the starting complex was consumed and converted into the expected free-base corrole, ( $\mathrm{T} t \mathrm{Bu} \mathrm{PCor}) \mathrm{H}_{3}$ in good yield, with no evidence of an isocorrole. 
It should be mentioned that reduction of the silver ion in this experiment proceeded to its $\operatorname{Ag}(0)$ form, as determined from the typical silver mirror layered on the glass surface. This is similar to what was reported during the demetalation of silver porphyrinates. ${ }^{11}$ Application of the same protocol to the silver(III) $\beta$-nitro corrolates could open the way to the corresponding free-base corrole, an appealing compound never reported in literature. When we carried out the reaction on $\left(\mathrm{NO}_{2} \mathrm{TTC}\right.$ r) $) \mathrm{Ag}$ we observed a considerable change in the visible spectrum consistent with formation of a free-base corrole after only $10 \mathrm{~min}$. TLC analysis revealed the complete disappearance of the starting complex and formation of a green band having a lower $\mathrm{R}_{\mathrm{f}}$ value than the silver nitrocorrole as the main product. The solution was filtered on Celite to remove the generated $\operatorname{Ag}(0)$ and then purified on a chromatographic column. Unfortunately this compound was quite labile on silica and mostly decomposed during elution. However traces of the product could be collected and were used for spectroscopic characterization. The proton NMR spectrum is reported in Figure 2.

The identification of this product as $\left(\mathrm{NH}_{2} \mathrm{TTCor}\right) \mathrm{H}_{3}$ was unexpected, since sodium borohydride is able to reduce aromatic nitro compounds only in catalytic processes that employ metal catalysts such as Pt, Pd, or Ru supported on active carbon, polymers, and metal oxides, or Raney-Ni catalysts. ${ }^{20}$ A plausible explanation for this result derives from the recent development of novel catalytic systems based on silver nanoparticles, which have been used for the selective hydrogenation of a range of chloronitrobenzenes ${ }^{21}$ and 4nitroaniline. ${ }^{22}$ Considering these catalytic processes, we propose a mechanism for the demetalation/reduction of the silver nitrocorrole to the aminocorrole where $\mathrm{NaBH}_{4}$ first reduces $\mathrm{Ag}(\mathrm{III})$ to $\mathrm{Ag}(\mathrm{I})$ and then is dissociated from the macrocycle and reduced to silver metal in the solution. This process leads to the formation of $\operatorname{Ag}(0)$ nanoparticles that constitute the catalytic system responsible for reduction of the nitro group to an amino group.

The above-described demetalation method can be successfully employed for the demetalation of silver triarylcorrolates but it is not suitable for the corresponding nitro derivatives since it causes peripheral modification of the macrocycle. Because the free-base $\mathrm{NO}_{2}$-corrole is particularly appealing for further functionalizations, ${ }^{10}$ a different demetalation procedure for such compounds is necessary.

During our studies involving peripheral functionalization of the corrole macrocyle, we investigated the possibility of exploiting silver nitrocorrolate as a substrate for preparation of a $\beta$-fused pyrrolocorrole, an appealing starting compound for construction of more elaborated $\beta$-fused architectures with potential optoelectronic features. Such a compound could be obtained through application of the Barton-Zard procedure, which similarly affords $\beta$-fused pyrroloporphyrins ${ }^{23}$ by reaction of some (2-nitro-5,10,15,20-tetraphenylporphyrinato) metal complexes with a-isocyanoacetic esters in the presence of 1,8diazabicyclo[5.4.0] undec-7-ene (DBU). For this purpose we reacted $\left(\mathrm{NO}_{2} \mathrm{~T} t B u \mathrm{PCor}\right) \mathrm{Ag}$ with ethyl isocyanoacetate in a dry refluxing $\mathrm{THF} / \mathrm{Pr}-\mathrm{OH}$ solvent mixture, using excess of DBU as base. After $3 \mathrm{~h}$, TLC analysis showed the starting material to be fully consumed, and a main green compound was formed. The reaction product was purified by column chromatography after which the first green eluted fraction was isolated and spectral characterization indicated it to be $\left(\mathrm{NO}_{2} \mathrm{~T} t B u \mathrm{PCor}\right) \mathrm{H}_{3}$.

The UV-vis spectrum of this compound is quite uncommon among tetrapyrrolic macrocycles, having an unusual Soret band which is split into three bands of similar intensity at 397,438 , and $465 \mathrm{~nm}$. There is also a broadband at about $600 \mathrm{~nm}$ (Supporting Information, Figure S1). FAB mass spectrometry showed the compound to have a molecular peak at $\mathrm{m} / z 740$, and the ${ }^{1} \mathrm{HNMR}$ spectrum showed a singlet at $9.08 \mathrm{ppm}$, corresponding to the resonance of the proton on $\mathrm{C} 2$, which is shifted upfield with respect to the starting 
complex. To confirm our assignment, we dissolved the compound in pyridine and added excess silver acetate; in a few minutes silver insertion was shown to be successful by both $\mathrm{UV}-\mathrm{vis}$ and TLC monitoring, and $\left(\mathrm{NO}_{2} \mathrm{~T} t \mathrm{Bu} \mathrm{PCor}\right) \mathrm{Ag}$ was recovered.

Prompted by these unexpected results, we decided to test the effectiveness of the demetalation system constituted by DBU/THF. We dissolved (T $t B u$ PCor)Ag in THF, added a 20-fold excess of DBU, and monitored the course of the reaction by UV-vis spectroscopy. In about $30 \mathrm{~min}$, the visible spectrum showed the appearance of a new, distinct band at 638 $\mathrm{nm}$ which is ascribed to the corrole anion radical. After $18 \mathrm{~h}$, TLC analysis indicated the complete disappearance of the silver complex, and UV-vis monitoring evidenced the typical optical profile of the corrole anion, having a split Soret band at 421 and $443 \mathrm{~nm}$ and a strong Q-band at $638 \mathrm{~nm}$. It is important to note that precipitation of $\operatorname{Ag}(0)$ from the reaction was observed, indicating that a reductive demetalation mechanism was also occurring in this system.

After workup, TLC analysis showed the free-base corrole, ( $\mathrm{T} t \mathrm{Bu} \mathrm{PCor}) \mathrm{H}_{3}$ to be the main product together with a less polar brown compound which was not easily separated from the corrole by column chromatograph. However treatment of the fractions containing these two compounds with hydrazine converted the brown compound into the corrole, increasing the final yield. When the same method was applied to $\left(\mathrm{NO}_{2} \mathrm{~T} t \mathrm{Bu} \mathrm{PCor}\right) \mathrm{Ag}$, removal of the silver ion from the macrocycle was rapid and exhaustive and occurred in about $30 \mathrm{~min}$. Chromatographic purification afforded a single compound, whose spectroscopic features indicated it to be the corresponding free-base $\left(\mathrm{NO}_{2} \mathrm{Tt} B u \mathrm{PCor}\right) \mathrm{H}_{3}$.

To obtain further information on the demetalation mechanism under basic conditions, we decided to verify if a strong base, such as $\mathrm{NaOH}$ in ethanol/toluene solution, could represent an effective demetalation system for silver corrolates. We dissolved (TtBuPCor)Ag in the alcoholic mixture and added a large excess of sodium hydroxide. The reaction was refluxed for about $1.5 \mathrm{~h}$, until TLC analysis indicated quantitative formation of the red-brown spot, corresponding to what was observed in the case of the DBU/THF system, together with traces of the starting compound. After the necessary workup to neutralize the excess base, purification on silica gel afforded the compound, which could be converted in moderate yield $(38 \%)$ to the expected corrole using hydrazine. An application of the described route to the corresponding nitro derivative led to rapid formation of a mixture of isocorrole species and only traces of the expected demetalated corrole could be detected.

\section{Electrochemistry in Pyridine}

Five $\mathrm{Ag}(\mathrm{III})$ corroles were selected for electrochemical characterization in pyridine. Each compound could be reduced to its $\mathrm{Ag}(\mathrm{II})$ and $\mathrm{Ag}(\mathrm{I})$ forms, and both electrode reactions were followed by demetalation in solution to give a corrole product, identified as $\left[(\mathrm{Cor}) \mathrm{H}_{2}\right]^{-}$on the basis of its UV-visible spectrum and electrochemistry, previously characterized in pyridine for a number of derivatives having meso-substituents similar to the species investigated in the current study. ${ }^{17}$

The most stable of the five electrochemically investigated $\mathrm{Ag}(\mathrm{III})$ corroles is $\left(\mathrm{TF}_{5} \mathrm{PCor}\right) \mathrm{Ag}$ whose cyclic voltammogram is illustrated in Figure 3. Four redox processes are observed. Two are assigned to metal-centered reactions of the initial compound (at $E_{1 / 2}=-0.55 \mathrm{~V}$ and $E_{\mathrm{p}}=-1.42 \mathrm{~V}$ ) and two to the diprotic corrole demetalation product, in this case $\left[\left(\mathrm{TF}_{5} \mathrm{PCor}\right) \mathrm{H}_{2}\right]^{-}$, which is reversibly reduced to $\left[\left(\mathrm{TF}_{5} \mathrm{PCor} \mathrm{H}_{2}\right]^{2-}\right.$ at $E_{1 / 2}=-1.62 \mathrm{Vand}$ reversibly oxidized to $\left[\left(\mathrm{TF}_{5} \mathrm{P} \cdot \mathrm{Cor}\right) \mathrm{H}_{2}\right]$ at $E_{1 / 2}=0.38 \mathrm{~V}$.

The initial $\mathrm{Ag}^{\mathrm{III}} / \mathrm{Ag}^{\mathrm{II}}$ process of $\left(\mathrm{TF}_{5} \mathrm{PCor}\right) \mathrm{Ag}$ is reversible at a scan rate of $0.1 \mathrm{~V} / \mathrm{s}$, when the negative potential sweep is terminated prior to the generation of a transient 
$\left[\left(\mathrm{TF}_{5} \mathrm{PCor}\right) \operatorname{CorAg}(\mathrm{I})\right]^{2-}$ species at $E_{\mathrm{p}}=-1.42 \mathrm{~V}$. Under these conditions, there is little to no demetalation on the cyclic voltammetry time scale (see Figure 3 ). However, when scanning beyond the second reduction, a rapid demetalation results as indicated by the two reversible processes at $E_{1 / 2}=-1.62$ and $0.38 \mathrm{~V}$ on the return sweep.

Two metal-centered reductions followed by demetalation are also seen for the other corroles on the cyclic voltammetry time scale, as shown in Figures 4 and 5 for (TTCor)Ag and ( $\mathrm{T} t B u \mathrm{PCor}) \mathrm{Ag}$, respectively, both of which were also investigated by thin-layer spectroelectrochemistry. In both cases, the demetalation product is reversibly reduced or oxidized at potentials similar to those of related free-base meso-substituted corroles under the same solution conditions. ${ }^{17}$ The half-wave potentials of the demetalation product are given in Table 1, along with values of $E_{1 / 2}$ or $E_{\mathrm{p}}$ for the metal-centered reactions of the initial compound.

The voltammetric data in Figures 3-5 are consistent with the metal-centered reductions and coupled demetalation reactions shown in Scheme 1. The same corrole demetalation product is generated after the first and second electron additions and is assigned as $\left[(\mathrm{Cor}) \mathrm{H}_{2}\right]^{-}$where Cor represents one of the macrocycles in Chart $1 . \operatorname{Ag}(\mathrm{I})$ and $\operatorname{Ag}(0)$ redox reactions are also detected in the cyclic voltammogram of Figures 4 and 5 and located at $E_{\mathrm{pc}}=-0.33$ to -0.38 $\mathrm{V}$ (reduction) and $E_{\mathrm{pa}}=-0.08$ to $-0.09 \mathrm{~V}$ (oxidation). These processes are indicated by an asterisk in the figures and occur at potentials close to peak potentials for the reduction and reoxidation of $\mathrm{AgBF}_{4}$ in pyridine containing 0.1 M TBAP (Figure 4b).

The mechanism shown in Scheme 1 was confirmed by examining the products of each electrode reaction in a thin-layer UV-vis cell, and examples of the spectroelectrochemical data are given in Figures 6 and 7. The first reduction generates a stable $\mathrm{Ag}^{\mathrm{II}}$ corrole in the case of $\left(\mathrm{TF}_{5} \mathrm{PCor}\right) \mathrm{Ag}$ (Figure 6a) which has bands at 442, 592, and $609 \mathrm{~nm}$, while ( $\mathrm{T} t B u$ PCor)Ag and $\left(\mathrm{NO}_{2}\right.$ TPCor)Ag show no evidence of a stable $\mathrm{Ag}$ II product on the spectroelectrochemical time scale. For these compounds only the deprotonated free-base corrole is observed after reduction. Several isosbestic points are observed, and the final product has bands at 430, 451, and $645 \mathrm{~nm}$ for $\left[(\mathrm{T} t B u P C o r) \mathrm{H}_{2}\right]^{-}$(Figure $6 \mathrm{~b}$ ) and 374, 407, 491,641 , and $687 \mathrm{~nm}$ for $\left[\left(\mathrm{NO}_{2} \mathrm{TPCor}\right) \mathrm{H}_{2}\right]^{-}$(Figure $\left.6 \mathrm{c}\right)$. These wavelengths are listed in Table 2.

Further reduction of the deprotonated product at more negative potentials leads to $\left[(\mathrm{Cor}) \mathrm{H}_{2}\right]^{2-}$ (see Scheme 1) as evidenced by the spectroelectrochemical data in Figure 7 which compares the spectral reduction product of $\left(\mathrm{TF}_{5} \mathrm{PCor}\right) \mathrm{Ag}$ and $\left(\mathrm{TF}_{5} \mathrm{PCor}\right) \mathrm{H}_{3}$ under the same solution conditions. As seen in the figure, identical spectra are obtained after each redox process of the two compounds.

\section{Conclusions}

The demetalation of silver(III) corrolates can represent a useful tool to further develop the synthetic chemistry of other corrole compounds. However, acidic demetalation conditions inevitably induce an oxidation of the corrole ring, which is particularly significant in the case of $\left(\mathrm{NO}_{2} \mathrm{TPCor}\right) \mathrm{H}_{3}$. This oxidation leads to the formation of isocorrole species, one of which was structurally characterized in the present study to illustrate that regioselective oxidation occurred at the 5-position of the corrole ring.

The formation of isocorroles can be avoided by using electrochemical reduction techniques or $\mathrm{NaBH}_{4}$ as a chemical reductant, although the chemical route cannot be used in the case of 3- $\mathrm{NO}_{2}$ substituted corroles, because of reduction of the nitro group, with formation of the 3$\mathrm{NH}_{2}$ corrole. However, demetalation can be obtained for the same compound in solution by using a DBU/THF solvent mixture. 
To investigate in greater detail the mechanism for demetalation of silver(III) corroles, we have examined the electrochemistry of selected $\mathrm{Ag}(\mathrm{III})$ corrole complexes and have elucidated the stepwise $\mathrm{Ag}(\mathrm{III}) / \mathrm{Ag}$ (II) and $\mathrm{Ag}$ (II)/Ag(I) reactions that occur prior to a rapid demetalation. The use of electrochemical or chemical demetalation procedures using DBU/ THF can be particularly useful for synthetic purposes and should remove one of the remaining obstacles that has slowed down the development of corrole chemistry.

\section{Supplementary Material}

Refer to Web version on PubMed Central for supplementary material.

\section{Acknowledgments}

The support of Italian MiUR (PRIN project no. 2007C8RW53) and the Robert A. Welch Foundation (K.M.K., Grant E-680) are gratefully acknowledged.

\section{References}

1. (a) Pandey, RK.; Zheng, G. In The Porphyrin Handbook. Kadish, KM.; Smith, KM.; Guilard, R., editors. Vol. 6. Academic Press; San Diego: 2000. p. 157(b) Kessel DJ. Porphyrins Phthalocyanines. 2008; 12:877.

2. Aida, T.; Inoue, S. The Porphyrin Handbook. Kadish, KM.; Smith, KM.; Guilard, R., editors. Vol. 6. Academic Press; San Diego: 2000. p. 133

3. (a) Paolesse, R. In The Porphyrin Handbook. Kadish, KM.; Smith, KM.; Guilard, R., editors. Vol. 2. Academic Press; San Diego: 2000. p. 201(b) Guilard, R.; Barbe, J-M.; Stern, C.; Kadish, KM. In The Porphyrin Handbook. Kadish, KM.; Smith, KM.; Guilard, R., editors. Vol. 18. Academic Press; San Diego: 2003. p. 303(c) Gryko DT, Fox JP, Goldberg DPJ. Porphyrins Phthalocyanines. 2004; 8:1091.(d) Nardis S, Monti D, Paolesse R. Mini-Rev Org Chem. 2005; 2:546.

4. Palmer JH, Day MW, Wilson AD, Henling LM, Gross Z, Gray HB. J Am Chem Soc. 2008; 130:7786. and references therein. [PubMed: 18512923]

5. Walker FA, Licoccia S, Paolesse R. J Inorg Biochem. 2006; 100:810. and references therein. [PubMed: 16519943]

6. Aviv I, Gross Z. Chem Commun. 2007:1987.

7. Paolesse R. Synlett. 2008; 15:2215.

8. (a) Stefanelli M, Mastroianni M, Nardis S, Licoccia S, Fronczek FR, Smith KM, Zhu W, Ou Z, Kadish KM, Paolesse R. Inorg Chem. 2007; 46:10791. [PubMed: 17985873] (b) Mastroianni M, Zhu W, Stefanelli M, Nardis S, Fronczek FR, Smith KM, Ou Z, Kadish KM, Paolesse R. Inorg Chem. 2008; 47:11680. [PubMed: 18998630]

9. (a) Bröring M, Hell C. Chem Commun. 2001:2336.(b) Brückner C, Barta CA, Briñas RP, Krause Baue JA. Inorg Chem. 2003; 42:1673. [PubMed: 12611538] (c) Mandoj F, Nardis S, Pomarico G, Paolesse R. J Porphyrins Phthalocyanines. 2008; 12:19.(d) Capar C, Kolle ET, Ghosh A. J Porphyrins Phthalocyanines. 2008; 12:964.(e) Ngo TH, Van Rossom W, Dehaen W, Maes W. Org Biomol Chem. 2009; 7:439. [PubMed: 19156307]

10. Jaquinod, L. The Porphyrin Handbook. Kadish, KM.; Smith, KM.; Guilard, R., editors. Vol. 1. Academic Press; San Diego: 2000. p. 201

11. Kadish KM, Lin QX, Ding JQ, Wu YT, Araullo C. Inorg Chem. 1986; 25:3236.

12. (a) Paolesse R, Nardis S, Sagone F, Khoury RG. J Org Chem. 2001; 66:550. [PubMed: 11429828] (b) Paolesse R, Marini A, Nardis S, Froiio A, Mandoj F, Nurco DJ, Prodi L, Montalti M, Smith KM. J Porphyrins Phthalocyanines. 2003; 7:25.

13. Lin XQ, Kadish KM. Anal Chem. 1985; 57:1498-1501. [PubMed: 4037326]

14. Ou Z, Sun H, Zhu W, Da Z, Kadish KM. J Porphyrins Phthalocyanines. 2008; 12:1.

15. Nardis S, Pomarico G, Fronczek FR, Vicente MGH, Paolesse R. Tetrahedron Lett. 2007; 48:8643.

16. Ishizuka T, Yamasaki H, Osukab A, Furuta H. Tetrahedron. 2007; 63:5137. 
17. Shen J, Shao J, Ou ZEW, Koszarna B, Gryko DT, Kadish KM. Inorg Chem. 2006; 45:2251. [PubMed: 16499391]

18. Collman JP, Bencosme SC, Durand RR Jr, Kreh RP, Anson FC. J Am Chem Soc. 1983; 105:2699.

19. Cowan JA, Sanders JRM. Tetrahedron Lett. 1986; 27:1201.

20. (a) Tafesh AM, Weiguny J. Chem Rev. 1996; 96:2035. [PubMed: 11848820] (b) Downing RS, Kunkeler PJ, van Bekkum H. Catal Today. 1997:121.

21. Chen Y, Wang C, Liu H, Qiu J, Bao X. Chem Commun. 2005:5298.

22. Zhou Q, Qian G, Li Y, Zhao G, Chao Y, Zheng J. Thin Solid Films. 2008; 516:953-956.

23. (a) Jaquinod L, Gros C, Olmstead MM, Antolovich M, Smith KM. Chem Commun. 1996:1475.(b) Gros CP, Jaquinod L, Khoury RG, Olmstead MM, Smith KM. J Porphyrins Phthalocyanines. 1997; 1:201. 


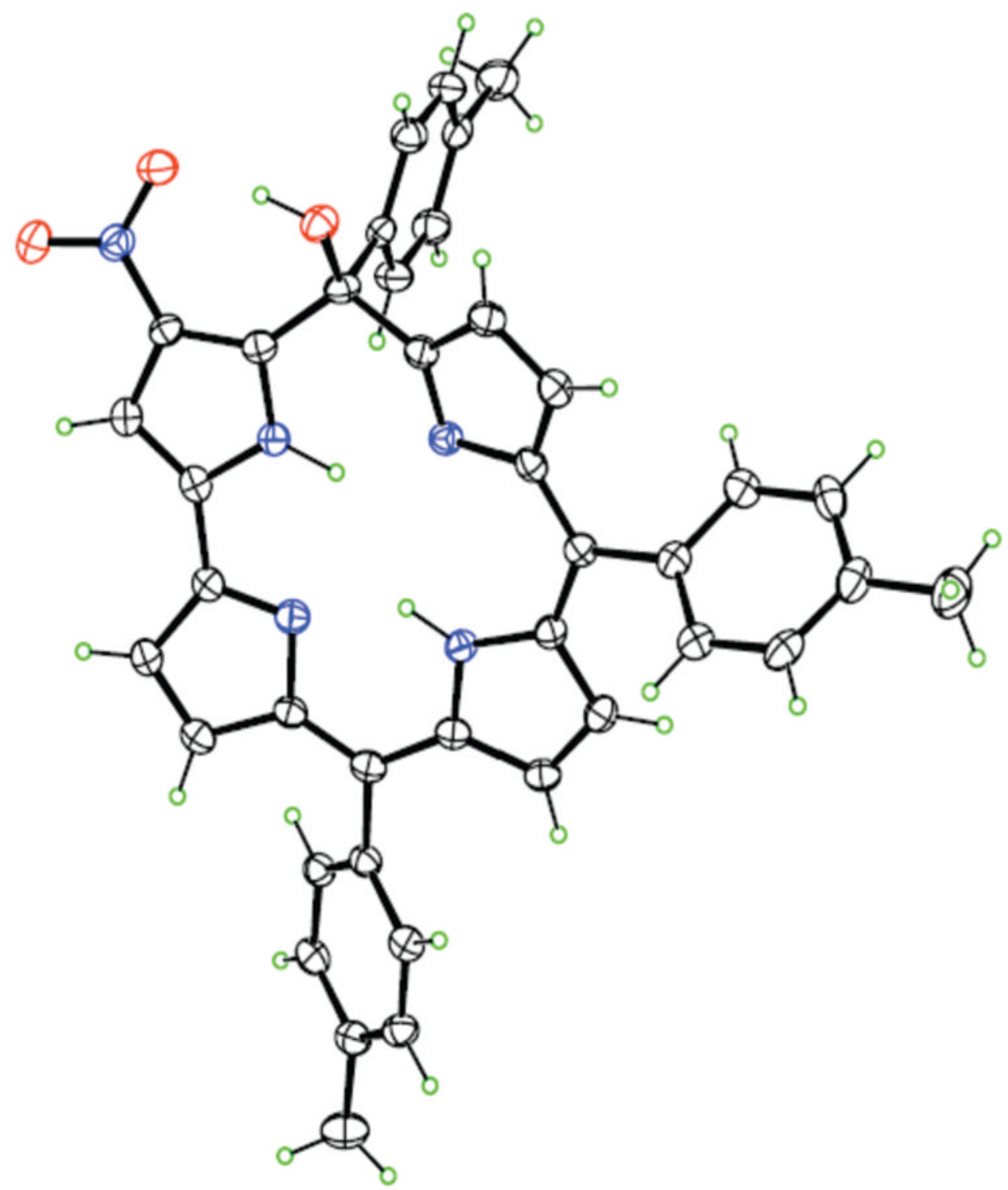

Figure 1.

Molecular structure of $\left[\left(3-\mathrm{NO}_{2}\right)(5-\mathrm{OH}) \mathrm{TT}\right.$ TisoCor $] \mathrm{H}_{2}$. 


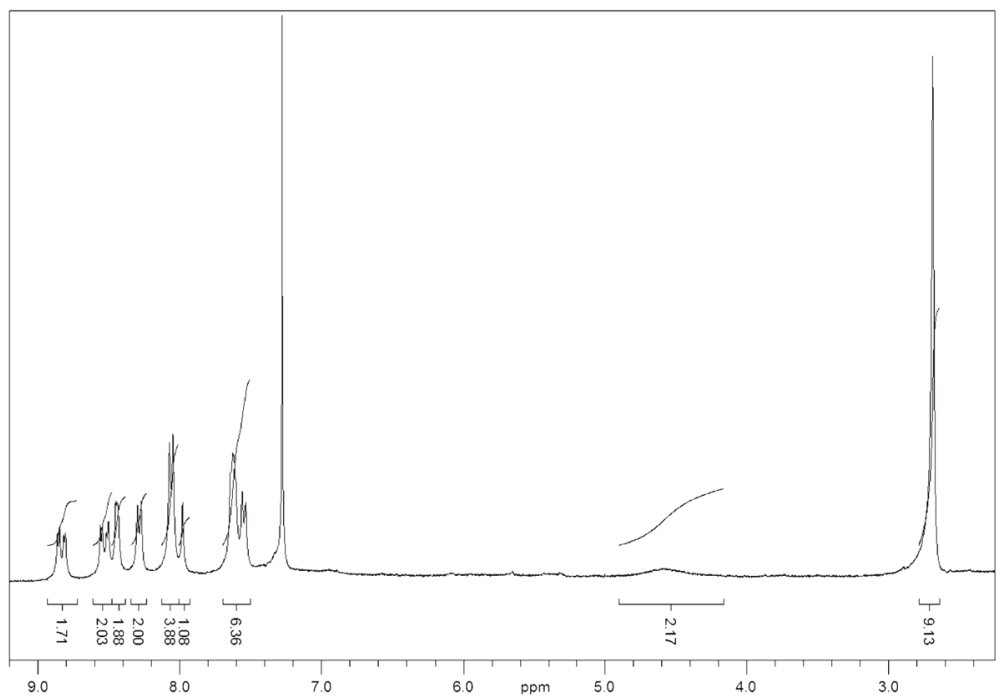

Figure 2.

${ }^{1} \mathrm{H}$ NMR spectrum of $\left(\mathrm{NH}_{2} \mathrm{TTCor}\right) \mathrm{H}_{3}$. 


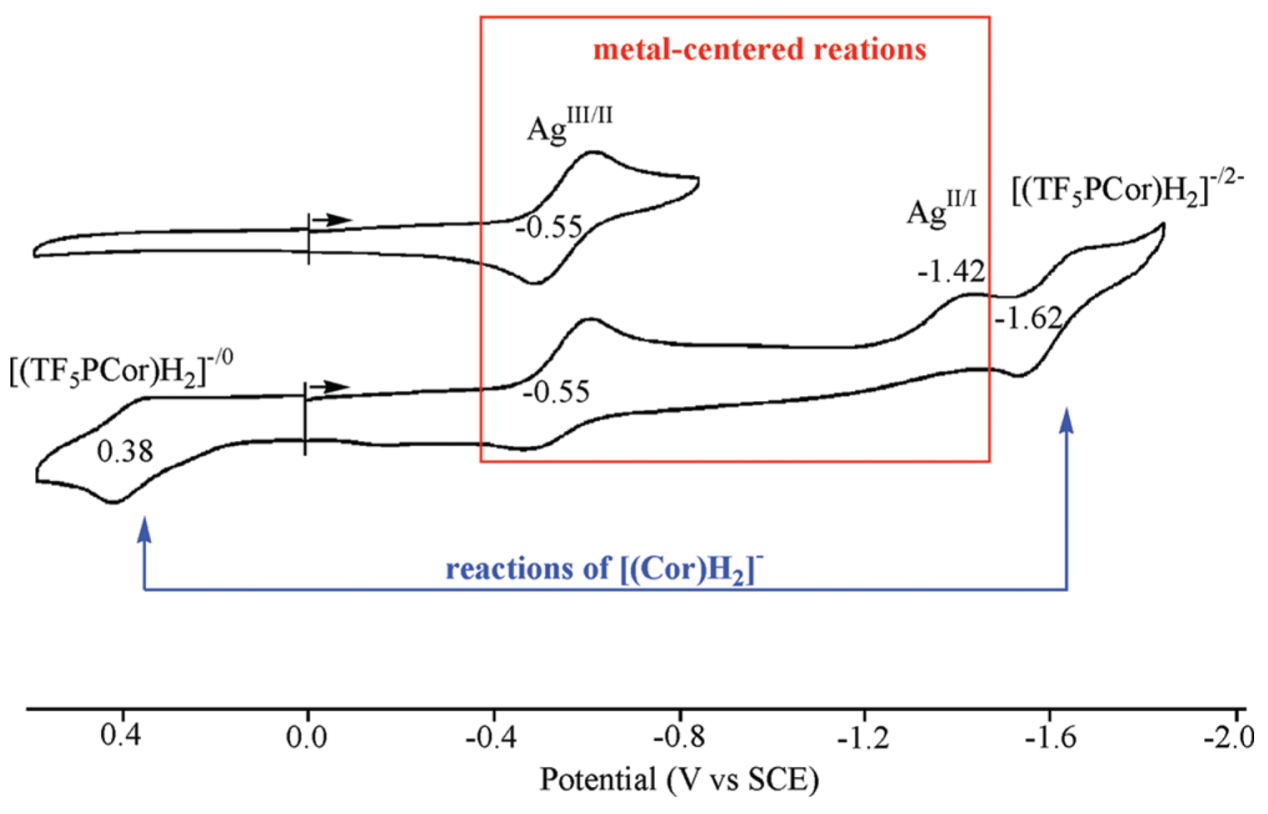

Figure 3.

Cyclic voltammograms of $\left(\mathrm{TF}_{5} \mathrm{PCor}\right) \mathrm{Ag}$ in pyridine containing $0.1 \mathrm{M}$ TBAP. 


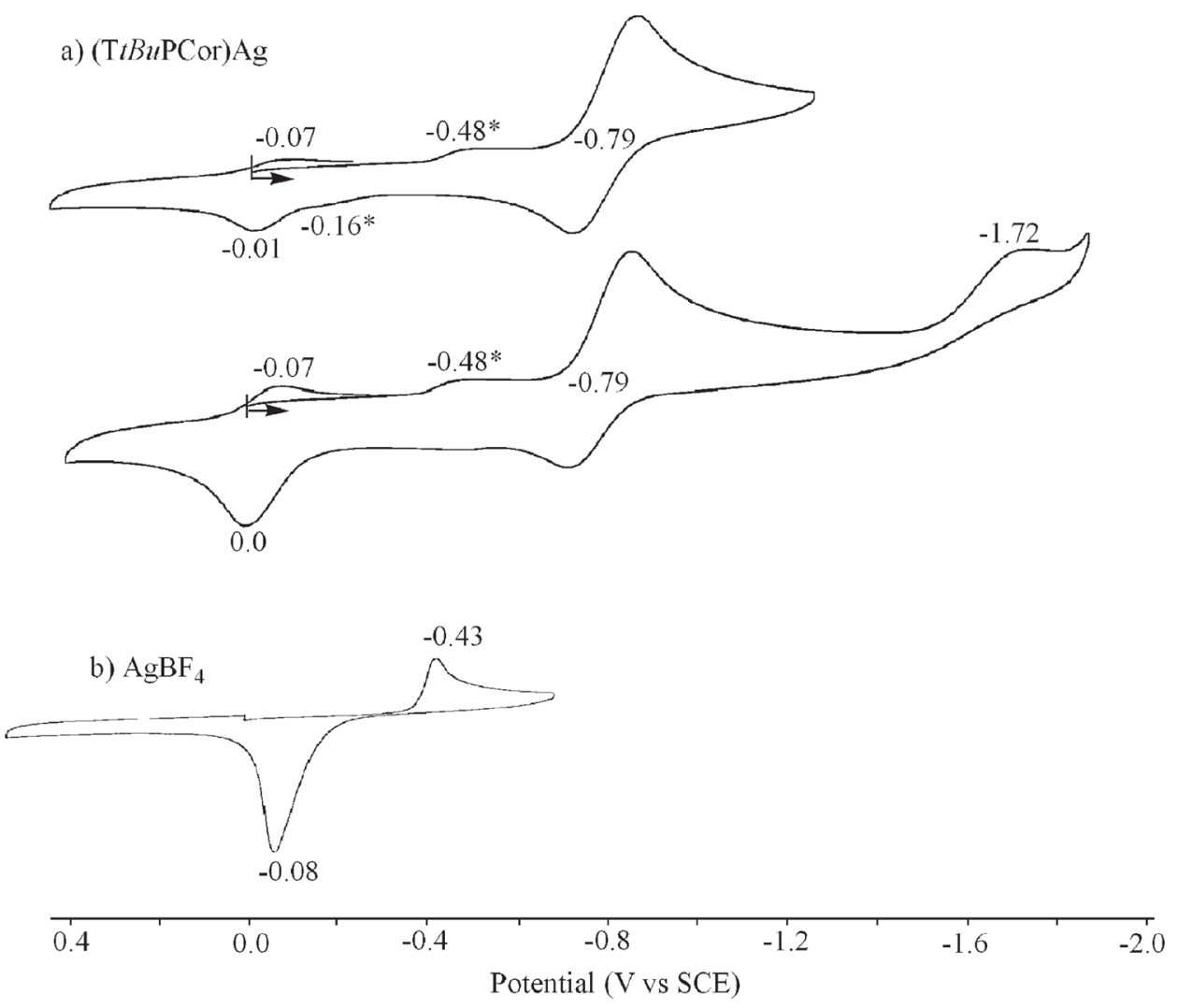

Figure 4.

Cyclic voltammograms of (a) (TtBuPCor) $\mathrm{Ag}$ and (b) $\mathrm{AgBF}_{4}$ in pyridine containing $0.1 \mathrm{M}$ TBAP. The electrode reactions involving dissociated $\mathrm{Ag}^{\mathrm{I}}$ and $\mathrm{Ag}^{0}$ are indicated by *. 

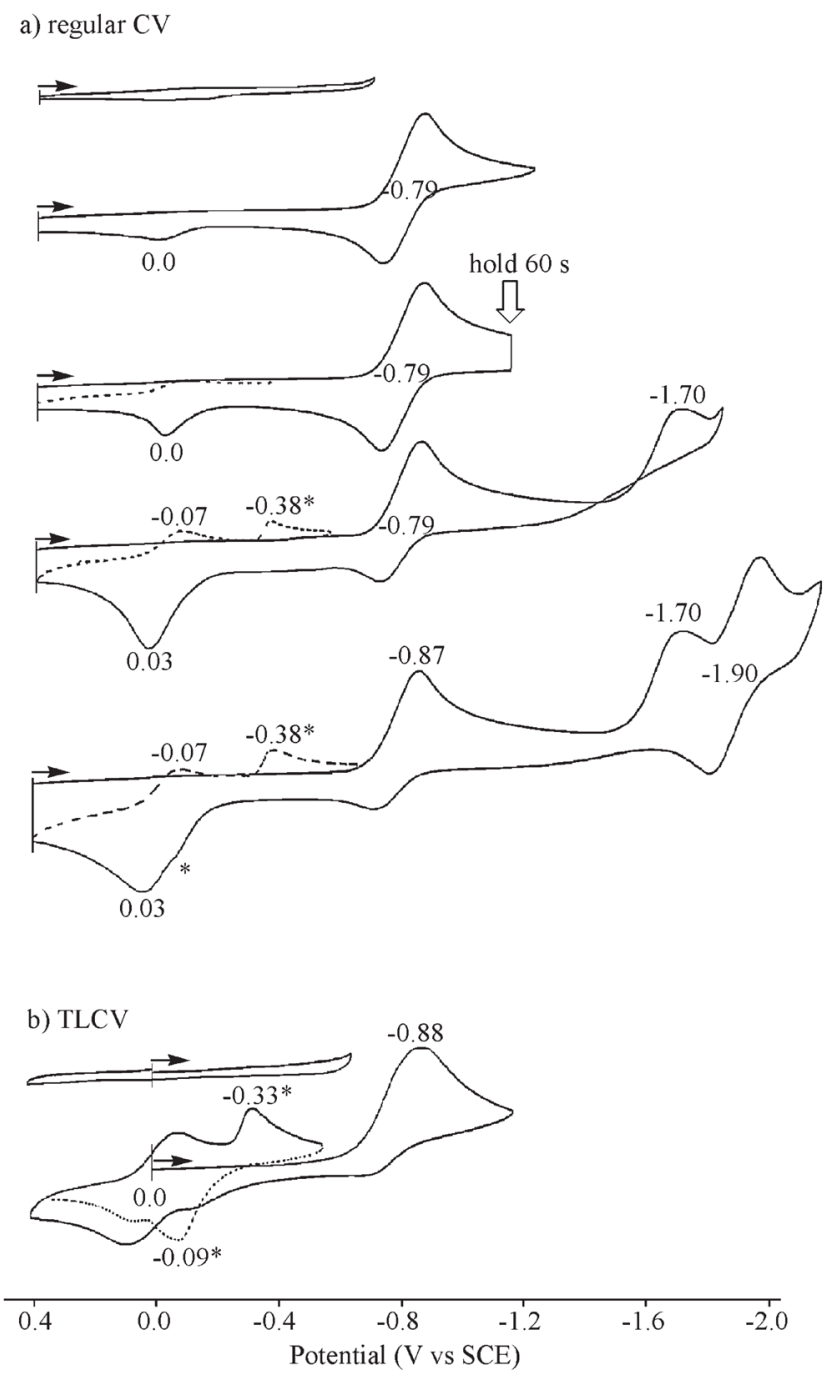

Figure 5.

(a) Regular and (b) thin-layer cyclic voltammograms of (TTCor)Ag in pyridine containing 0.1MTBAP. The electrode reactions involving free $\mathrm{Ag}^{\mathrm{I}}$ and $\mathrm{Ag}^{0}$ are indicated by *. 


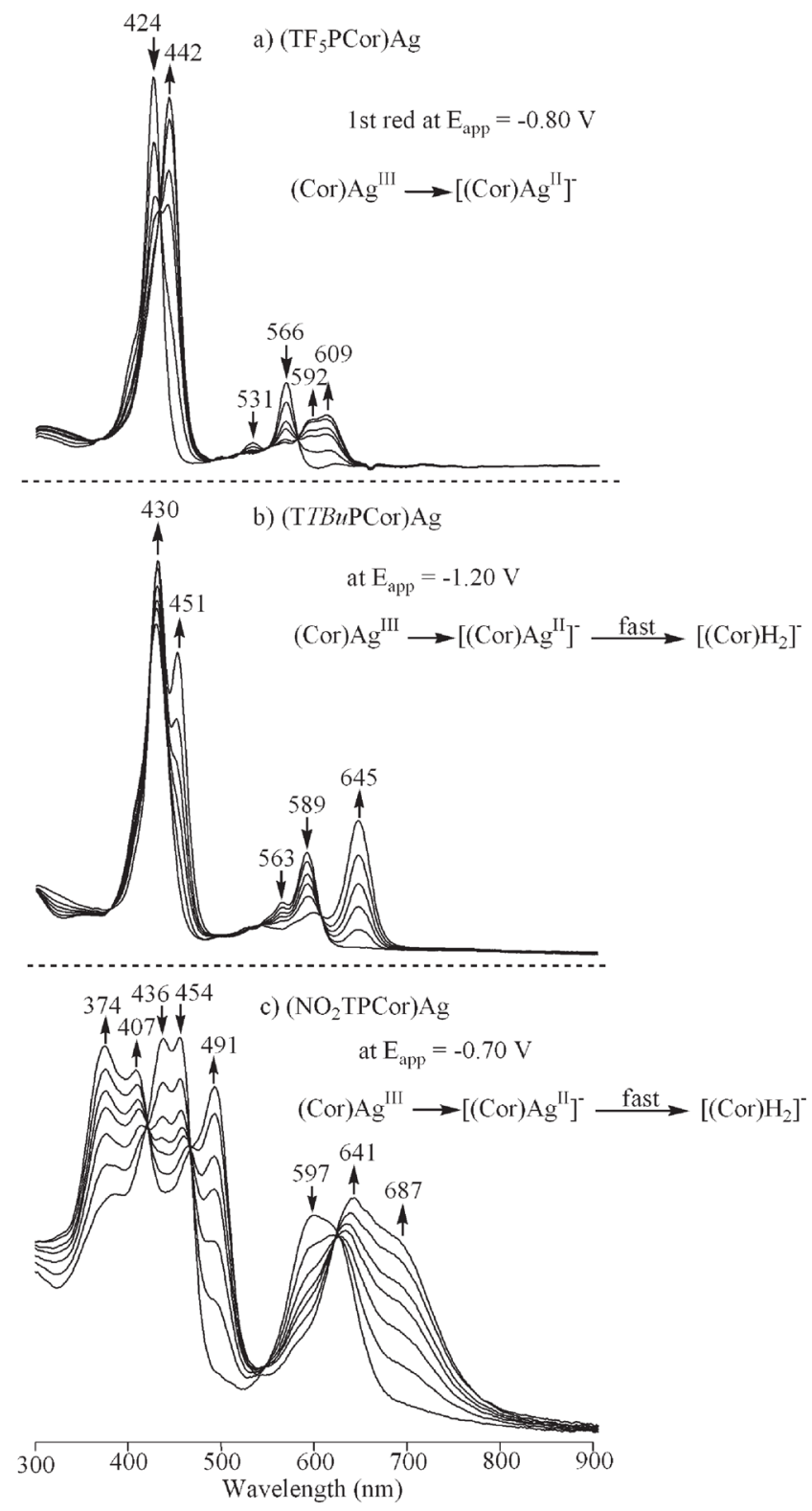

Figure 6.

$\mathrm{UV}$-visible spectral changes during the first reduction of (a) $\left(\mathrm{TF}_{5} \mathrm{PCor}\right) \mathrm{Ag}$, (b) (TtBuPCor)Ag, and (c) ( $\mathrm{NO}_{2}$ TPCor)Ag in py, 0.1 M TBAP. 
a) product of $\left(\mathrm{TF}_{5} \mathrm{PCor}\right) \mathrm{Ag}$ reduction

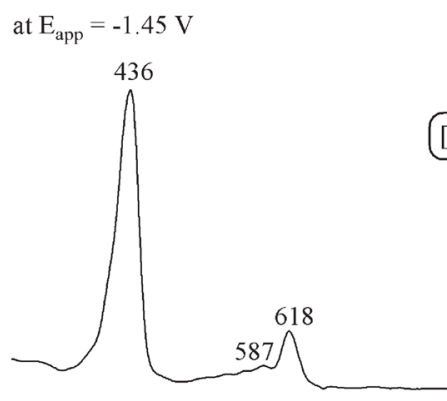

b) product of $\left(\mathrm{TF}_{5} \mathrm{PCor}\right) \mathrm{H}_{3}$ reduction

at $\mathrm{E}_{\text {app }}=-1.00 \mathrm{~V}$ at $\mathrm{E}_{\mathrm{app}}=-1.80 \mathrm{~V}$

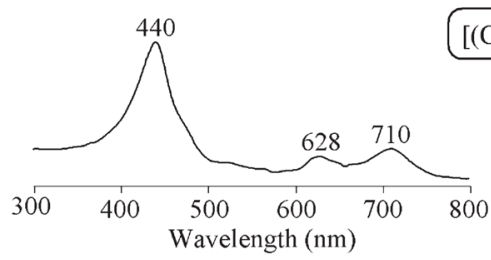

$\left[(\mathrm{Cor}) \mathrm{H}_{2}\right]$

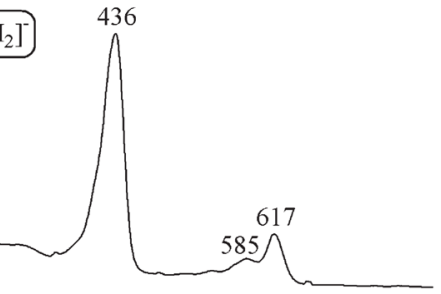

at $\mathrm{E}_{\text {app }}=-1.80 \mathrm{~V}$

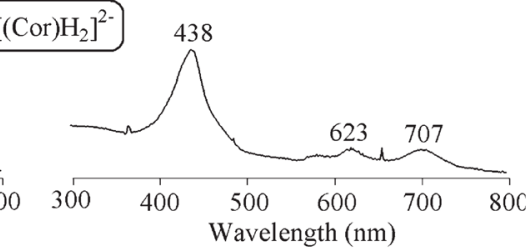

Figure 7.

UV-visible spectra of the singly and doubled reduced forms of (a) $\left(\mathrm{TF}_{5} \mathrm{PCor}\right) \mathrm{Ag}$ and (b) $\left(\mathrm{TF}_{5} \mathrm{PCor}\right) \mathrm{H}_{3}$ in py containing $0.1 \mathrm{M}$ TBAP to give $\left[(\mathrm{Cor}) \mathrm{H}_{2}\right]^{-}$and $\left[(\mathrm{Cor}) \mathrm{H}_{2}\right]^{2-}$. 


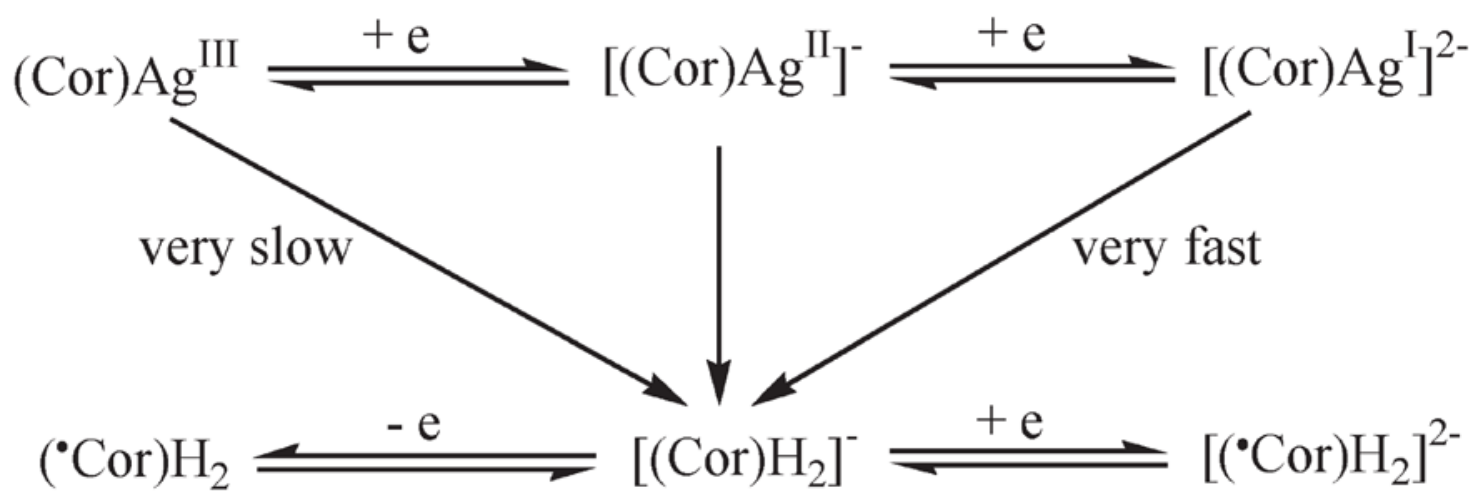

Scheme 1.

Demetalation of Neutral and Reduced Silver Corroles in Pyridine 

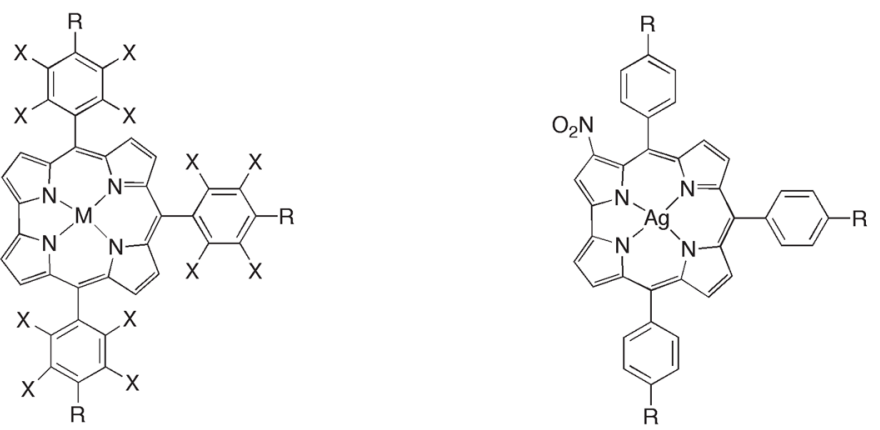

$\begin{array}{llll}\text { (TPCor) } \mathrm{H}_{3} & \mathrm{R}=\mathrm{X}=\mathrm{H} & & \mathrm{M}=\mathrm{H}_{3} \\ (\text { TTCor }) \mathrm{H}_{3} & \mathrm{R}=\mathrm{CH}_{3} & \mathrm{X}=\mathrm{H} & \mathrm{M}=\mathrm{H}_{3} \\ \left(\text { TtBuPCor) } \mathrm{H}_{3}\right. & \mathrm{R}=\text { tert-butyl } & \mathrm{X}=\mathrm{H} & \mathrm{M}=\mathrm{H}_{3} \\ \left(\mathrm{TF}_{5} \text { PCor) } \mathrm{H}_{3}\right. & \mathrm{R}=\mathrm{X}=\mathrm{F} & & \mathrm{M}=\mathrm{H}_{3} \\ \text { (TPCor)Ag } & \mathrm{R}=\mathrm{X}=\mathrm{H} & & \mathrm{M}=\mathrm{Ag} \\ \text { (TTCor)Ag } & \mathrm{R}=\mathrm{CH}_{3} & \mathrm{X}=\mathrm{H} & \mathrm{M}=\mathrm{Ag} \\ \text { (TtBuPCor)Ag } & \mathrm{R}=\text { tert-butyl } & \mathrm{X}=\mathrm{H} & \mathrm{M}=\mathrm{Ag} \\ \text { (TF } F_{5} \text { PCor)Ag } & \mathrm{R}=\mathrm{X}=\mathrm{F} & & \mathrm{M}=\mathrm{Ag}\end{array}$

Chart 1.

Molecular Structures of the Corroles Studied 


\section{Table 1}

Half-Wave Potentials (V vs SCE) for Metal-Centered Reductions of Silver Corroles and Resulting Demetalation Product in Pyridine Containing 0.1 M TBAP (see Scheme 1)

\begin{tabular}{|c|c|c|c|c|}
\hline \multirow[b]{2}{*}{ cpd } & \multicolumn{2}{|c|}{ initial reductions } & \multicolumn{2}{|c|}{ reactions of demetalated corrole } \\
\hline & $\mathrm{Ag}^{\mathrm{III} / \mathrm{II}}$ & $\operatorname{Ag}^{\mathbf{I I} / \mathbf{I}}$ & oxidation & reduction \\
\hline$\left(\mathrm{TF}_{5} \mathrm{TPCor}\right) \mathrm{Ag}$ & -0.55 & $-1.42^{a}$ & 0.38 & -1.62 \\
\hline ( $\left.\mathrm{NO}_{2} \mathrm{TPCor}\right) \mathrm{Ag}$ & -0.52 & $-1.14^{a}$ & 0.23 & $-1.32,-1.78$ \\
\hline$\left(\mathrm{NO}_{2} t B u \mathrm{PCor}\right) \mathrm{Ag}$ & -0.54 & $-1.17^{a}$ & 0.21 & $-1.36,-1.74$ \\
\hline (TtBuPCor)Ag & -0.79 & $-1.72^{a}$ & -0.03 & -1.92 \\
\hline (TTCor)Ag & -0.79 & $-1.70^{a}$ & -0.04 & -1.90 \\
\hline
\end{tabular}

${ }^{a}$ Peak potential at a scan rate of $0.10 \mathrm{~V} / \mathrm{s}$. 


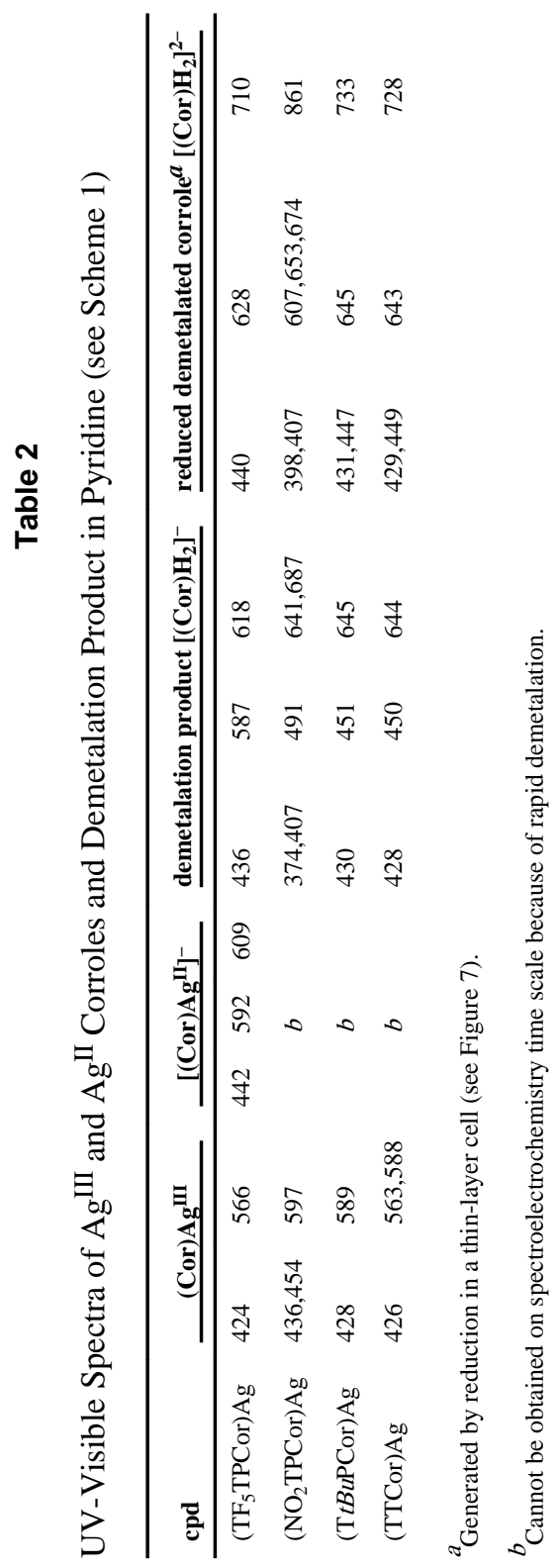

